\title{
Transition-Metal-Free Access to 2-Subsituted Indolines from Indoles via Dearomative Nucleophilic Addition Using Two-Molecule Organic Photoredox Catalysts
}

\author{
Yosuke Tanaka ${ }^{1}$, Takumi Ikeda ${ }^{1}$, Yasuhiro Nachi ${ }^{1}$, Taisei Mizuno ${ }^{1}$, Kousuke Maeda $^{1}$, Chisato Sakamoto $^{2}$, \\ Mugen Yamawaki ${ }^{2} \mathbb{D}$, Toshio Morita ${ }^{1}$ and Yasuharu Yoshimi ${ }^{1, * \mathbb{D}}$ \\ 1 Department of Applied Chemistry and Biotechnology, Graduate School of Engineering, University of Fukui, \\ 3-9-1 Bunkyo, Fukui 910-8507, Japan; you_sun_31@yahoo.co.jp (Y.T.); hd180071@g.u-fukui.ac.jp (T.I.); \\ mi210571@g.u-fukui.ac.jp (Y.N.); taimizu0000@gmail.com (T.M.); ebichujapan@hotmail.com (K.M.); \\ morita_t@u-fukui.ac.jp (T.M.) \\ 2 Department of Chemistry and Biology, National Institute of Technology, Fukui College, Genshi-cho, \\ Fukui 916-8507, Japan; sakamoto@fukui-nct.ac.jp (C.S.); yamawaki@fukui-nct.ac.jp (M.Y.) \\ * Correspondence: yyoshimi@u-fukui.ac.jp; Tel.: +81-776-27-8633
}

Citation: Tanaka, Y.; Ikeda, T.; Nachi, Y.; Mizuno, T.; Maeda, K.; Sakamoto, C.; Yamawaki, M.; Morita, T.; Yoshimi, Y. Transition-Metal-Free Access to 2-Subsituted Indolines from Indoles via Dearomative Nucleophilic Addition Using Two-Molecule Organic Photoredox Catalysts. Photochem 2021, 1, 448-457. https:// doi.org/10.3390/photochem 1030027

Received: 28 September 2021

Accepted: 20 October 2021

Published: 1 November 2021

Publisher's Note: MDPI stays neutral with regard to jurisdictional claims in published maps and institutional affiliations.

Copyright: (c) 2021 by the authors. Licensee MDPI, Basel, Switzerland. This article is an open access article distributed under the terms and conditions of the Creative Commons Attribution (CC BY) license (https:/ / creativecommons.org/licenses/by/ $4.0 /)$.

\begin{abstract}
A Photoinduced dearomative nucleophilic addition to N-Boc indoles mediated by twomolecule organic photoredox catalysts such as phenanthrene and 1,4-dicyanobenzene with UV irradiation furnished 2-substituted indolines in moderate to quantitative yields. Hydroxide, alkoxide, and cyanide ions can be used as a nucleophile to provide 2-hydroxy, 2-alkoxy, and 2-cyanoindolines, respectively. Both electron-rich and -deficient indoles, including tryptophan derivatives, can be employed in the photoreaction to provide various indolines. This method provides transitionmetal-free access to 2-subsituted indolines from indoles using organic photoredox catalysts under mild conditions.
\end{abstract}

Keywords: photoinduced dearomative nucleophilic addition; indole; 2-substituted indoline; organic photoredox catalyst

\section{Introduction}

The category of 2-substituted indolines, such as 2-hydroxy- and 2-alkoxy-indolines, are structural components of a myriad of interesting natural compounds and synthetic intermediates (Scheme 1a) [1-5]. Some naturally occurring substances in this family exhibit a variety of interesting pharmacological properties. The dearomatization of indoles constitutes the most efficient strategy for accessing indolines [6-9]. Common methods developed for the synthesis of 2-alkoxyindolines generally involve cyclization reactions of tryptophol catalyzed by transition metals, such as $\mathrm{Cu}, \mathrm{Sc}, \mathrm{Pd}, \mathrm{Ru}$, and Ir, under harsh conditions, such as high temperatures [10-15], although several approaches that utilize arylhydrizines [16,17], anilines [18,19], or spirocyclopropanes [20] have been reported. With the aim of developing synthetic approaches that utilize less toxic and more readily available reagents under mild conditions, we have been investigating photochemical reactions using organic photoredox catalysts, as they constitute environmentally friendly methods wherein light is applied as a traceless reagent, and harsh reaction conditions, such as high temperature and pressure, are not required. We have recently reported photoinduced electron transfer (PET)-promoted reactions of carboxylic acids [21-27], arylboronic acids [28], indene [29,30], and electron-rich alkenes [31] catalyzed by two-molecule organic photoredox catalysts, such as a combination of phenanthrene (Phen) as an electron donor and 1,4-dicyanobenzene (1,4-DCB) as an electron acceptor, under UV irradiation (313 nm) (Scheme 1b). This finding encouraged us to explore the PET-promoted decarboxylation of amino acids and peptides for their modification [32-35]. During this investigation, it was 
unexpectedly revealed that a dearomative nucleophilic addition to the indole unit of tryptophan derivatives occurred under these photochemical conditions to create 2-substituted indolines. Examples of photoreactions involving indoles, including the Diels-Alder reaction [36-38] and oxidation [39-41], have been limited due to the high stability of indole under photochemical conditions. Although dearomative radical addition to indoles mediated by photoredox catalysts has been disclosed [42,43], a dearomative nucleophilic addition to a radical cation of indole via PET to yield 2-subsituted indolines is rarely reported and entails the use of transition-metal (Ru or Ir) photocatalysts [44,45]. Herein, we describe the development of a simple and environmentally friendly photochemical method for the preparation of 2-substituted indolines from indoles using organic photoredox catalysts (Scheme 1c). In addition, the substrate and nucleophile scope and suitable organic photoredox catalysts are elucidated in the photoreaction.

a. Example of 2-substituted indolines<smiles>OC1Cc2ccccc2N1</smiles>

2-Hydroxyindoline<smiles>Cc1c([N+](=O)[O-])c(O)c2c(c1[N+](=O)[O-])C(CO)C1(O)C2C2CN1C2</smiles>

madindoline derivative<smiles>CCCN(CCC)CCc1cccc2c1CC(O)N2O</smiles>

Boc<smiles>CCCC1=CC(=O)C(C)(CN2c3ccccc3C3(O)CCOC23)C1=O</smiles><smiles>CCCN(CCC)CCc1ccccc1NC(C)=O</smiles>

ropinirole<smiles>[R]C1Cc2ccccc2N1</smiles>

2-Alkoxyindoline<smiles>CNC(=O)Oc1ccc2c(c1)CC1(C)CCCOC1N2C</smiles>

physovenine

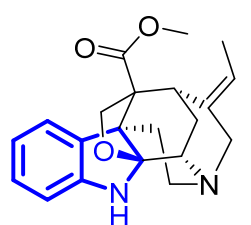

pseudoakuammigine

madindoline

b. Previous work

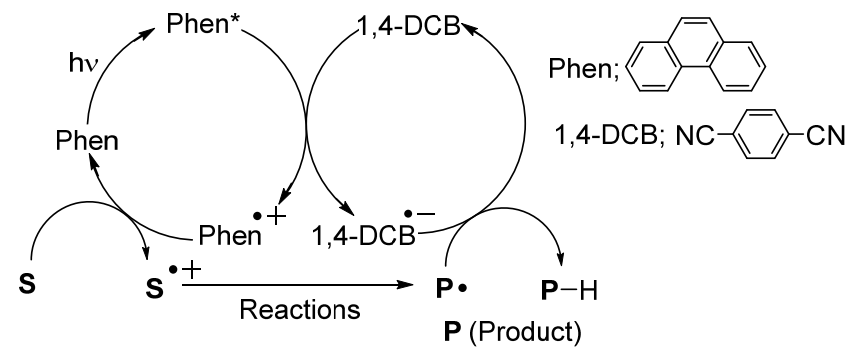<smiles>[R]OC=C=CCc1cccc2c1C=CC2</smiles>

\section{c. This Work}<smiles>[R]c1ccc2c(c1)c([R2])cn2C(C)=O</smiles>
Phen, 1,4-DCB or BP, 1,4-DCN $\mathrm{R}_{3} \mathrm{ONa}$ or $\mathrm{NaCN}$

$\mathrm{CH}_{3} \mathrm{CN} / \mathrm{H}_{2} \mathrm{O}$<smiles>[R16]c1ccc2c(c1)C([R2])C([R])N2</smiles><smiles>[R]C1c2cc([O-])ccc2N(C(C)=O)C1[R2]</smiles>

$\mathrm{R}_{1}=\mathrm{H}, \mathrm{Me}, \mathrm{F}, \mathrm{CN}, \mathrm{CO}_{2} \mathrm{Me}$

$\mathrm{R}_{2}=\mathrm{H}, \mathrm{Me}$

$\mathrm{R}_{3}=\mathrm{H}, \mathrm{Me}, \mathrm{Et}$

Scheme 1. (a) Examples of 2-hydroxy- and 2-alkoxy-indolines; (b) PET-promoted reactions of carboxylic acids, boronic acids, indene, and electron-rich alkenes (Previous work); (c) This work. 


\section{Materials and Methods}

General Information

All of the reagents and solvents were used as received from commercial suppliers. IR spectra were recorded on an FT-IR spectrometer (JASCO FT/IR-620, Tokyo, Japan). ${ }^{1} \mathrm{H}$ NMR spectra were recorded in $\mathrm{CDCl}_{3}$ containing tetramethylsilane as an internal standard and were acquired on a $500 \mathrm{MHz}$ spectrometer (JEOL JNM-ECX500, Tokyo, Japan). ${ }^{13} \mathrm{C}$ NMR spectra were acquired on a $125 \mathrm{MHz}$ spectrometer (JEOL JNM-ECX500). High-resolution mass spectra were obtained using double-focusing magnetic sector mass spectrometer coupled with FAB (JEOL JMS 700T, Tokyo, Japan). The UV-light source was a Riko UV-100HA high-pressure $(100 \mathrm{~W})$ mercury arc with cooling by water. Pyrex vessels $(18 \mathrm{~mm} \times 180 \mathrm{~mm})$ were directly attached to the light source $(\lambda>280 \mathrm{~nm}$, Phen or DCN mainly absorbs at $313 \mathrm{~nm}$ light). Column chromatography was performed on a Wakogel C-300 (Osaka, Japan), particle size $45-75 \mu \mathrm{m} .{ }^{1} \mathrm{H}$ and ${ }^{13} \mathrm{C}$ NMR spectra of $\mathbf{2 a}, \mathbf{b}, \mathbf{d}-\mathbf{g}, \mathbf{3}, \mathbf{4}, \mathbf{5}$, 7 were shown in Supplementary Materials.

\section{- General Procedure for the Preparation of $N$-Boc Indoles 1:}

$\mathrm{A} \mathrm{CH}_{2} \mathrm{Cl}_{2}$ solution $(40 \mathrm{~mL})$ of indoles $(4.3 \mathrm{mmol})$, triethylamine $(1.3 \mathrm{eq}, 5.6 \mathrm{mmol}$, $0.77 \mathrm{~mL}$ ), and DMAP (0.1 eq, $\left.4.3 \times 10^{-4} \mathrm{~mol}, 0.052 \mathrm{~g}\right)$ was added to $(\mathrm{Boc}){ }_{2} \mathrm{O}(1.2 \mathrm{eq}$, $5.2 \mathrm{mmol}, 1.2 \mathrm{~g})$ in $\mathrm{CH}_{2} \mathrm{Cl}_{2}(20 \mathrm{~mL})$ under an Ar atmosphere and was mixed overnight at room temperature. The resulting solution was acidified by the addition of $1 \mathrm{M} \mathrm{HCl} \mathrm{until}$ the $\mathrm{pH}$ decreased to 3, and it was extracted with $\mathrm{Et}_{2} \mathrm{O}$ three times and dried over $\mathrm{Na}_{2} \mathrm{SO}_{4}$, and the volatiles were removed through evaporation. The crude product was purified by silica-gel column chromatography using hexane/EtOAc as the eluent to yield $\mathrm{N}$-Boc indoles 1.

\section{- General Procedure for the Photoreaction of 1:}

An aqueous $\mathrm{CH}_{3} \mathrm{CN}$ solution $\left(\mathrm{CH}_{3} \mathrm{CN} 36 \mathrm{~mL}, \mathrm{H}_{2} \mathrm{O} 4 \mathrm{~mL}\right)$ of $\mathbf{1}(10 \mathrm{mM})$, Phen $(30 \mathrm{mM})$, DCB $(30 \mathrm{mM})$, and $\mathrm{NaOH}(10 \mathrm{mM})$ in Pyrex vessels $(18 \mathrm{~mm} \times 180 \mathrm{~mm})$ was purged with Ar for $10 \mathrm{~min}$. The mixture was irradiated using a $100 \mathrm{~W}$ high-pressure mercury lamp for $12 \mathrm{~h}$, and the solvent was then removed under reduced pressure. The crude product was purified by silica-gel column chromatography using hexane $/ \mathrm{Et}_{2} \mathrm{O}=20: 1$ to $10: 1$ as the eluent to yield adduct 2 . Photoreactions of $\mathbf{1}$ with $\mathrm{NaCN}$ or $\mathbf{6}$ without $\mathrm{NaOH}$ were performed under similar conditions to yield 5 or 7 , respectively.

Low rotation of the amide moiety and intramolecular hydrogen bonding between the hydroxy and carbonyl groups (Boc) of the obtained products gave rise to complex ${ }^{1} \mathrm{H}$ and ${ }^{13} \mathrm{C}$ NMR spectra with broadened peaks in $\mathrm{CDCl}_{3}$; low solubility of $2,3,4,5$, and 7 in $\mathrm{d}_{6}$-DMSO and $\mathrm{d}_{4}-\mathrm{MeOH}$ prevented their use to address this problem.

N-Boc 2-hydroxyindoline (2a): white solid; mp 59-61 ${ }^{\circ} \mathrm{C}$; IR $\left(\mathrm{KBr}, \mathrm{cm}^{-1}\right)$ 3452, 2975, 2930, 1685,$1612 ;{ }^{1} \mathrm{H}$ NMR $\left(500 \mathrm{MHz}, \mathrm{CDCl}_{3}\right) \delta 7.81(\mathrm{~s}(\mathrm{br}), 0.3 \mathrm{H}), 7.40(\mathrm{~s}(\mathrm{br}), 0.5 \mathrm{H}), 7.17(\mathrm{~m}, 2 \mathrm{H})$, $6.97(\mathrm{~m}, 1 \mathrm{H}), 6.01-5.92(\mathrm{~m}(\mathrm{br}), 1 \mathrm{H}), 4.11(\mathrm{~s}(\mathrm{br}), 0.6 \mathrm{H}), 3.34(\mathrm{~m}, 1.2 \mathrm{H}), 2.98(\mathrm{~d}, J=17.2 \mathrm{~Hz}$, $1 \mathrm{H}), 1.61(\mathrm{~s}, 9 \mathrm{H}) ;{ }^{13} \mathrm{C}$ NMR $\left(125 \mathrm{MHz}, \mathrm{CDCl}_{3}\right) \delta 153.4,151.3,141.1,140.2,128.7,127.2$, 125.0, 122.7, 114.4, 83.5, 82.6, 81.8, 36.3, 35.5, 28.5; HRMS (FAB, $m / z)$ calcd for $(\mathrm{M}+\mathrm{H})^{+}$ $\mathrm{C}_{13} \mathrm{H}_{18} \mathrm{NO}_{3}$ 236.1287, found 236.1276. N-Boc 2-hydroxy-5-methylindoline (2b): white solid; mp 88-90 ${ }^{\circ} \mathrm{C}$; IR $\left(\mathrm{KBr}, \mathrm{cm}^{-1}\right)$ 3450, 2955, 1685, 1612; ${ }^{1} \mathrm{H}$ NMR $\left(500 \mathrm{MHz}, \mathrm{CDCl}_{3}\right) \delta 7.67$ (s(br), 0.25H), $7.26(\mathrm{~s}(\mathrm{br}), 0.6 \mathrm{H}), 6.99(\mathrm{~m}, 2 \mathrm{H}), 6.00-5.90(\mathrm{~m}(\mathrm{br}), 1 \mathrm{H}), 4.07(\mathrm{~s}(\mathrm{br}), 0.5 \mathrm{H}), 3.30$ $(\mathrm{m}, 1.2 \mathrm{H}), 2.94(\mathrm{~d}, J=17.2 \mathrm{~Hz}, 1 \mathrm{H}), 1.60(\mathrm{~s}, 9 \mathrm{H}) ;{ }^{13} \mathrm{C} \mathrm{NMR}\left(125 \mathrm{MHz}, \mathrm{CDCl}_{3}\right) \delta$ 153.6, 138.0, 132.3, 128.8, 128.0, 125.8, 114.1, 83.7, 82.4, 81.7, 36.4, 35.6, 28.6, 21.0; HRMS (FAB, $m / z$ ) calcd for $(\mathrm{M}+\mathrm{H})^{+} \mathrm{C}_{14} \mathrm{H}_{20} \mathrm{NO}_{3} 250.1443$, found 250.1441. N-Boc 5-fluoro-2-hydroxyindoline (2d):

colorless oil; IR (neat, $\mathrm{cm}^{-1}$ ) 3455, 2950, 1690, 1615; $\left.{ }^{1} \mathrm{H} \mathrm{NMR} \mathrm{(500} \mathrm{MHz,} \mathrm{CDCl}_{3}\right) \delta 7.74$ (s(br), 0.3H), $7.32(\mathrm{~s}(\mathrm{br}), 0.5 \mathrm{H}), 6.88(\mathrm{~m}, 2 \mathrm{H}), 6.02-5.93(\mathrm{~m}(\mathrm{br}), 1 \mathrm{H}), 4.16(\mathrm{~s}(\mathrm{br}), 0.5 \mathrm{H}), 3.30$ $(\mathrm{m}, 1.3 \mathrm{H}), 2.95(\mathrm{~d}, J=17.0 \mathrm{~Hz}, 1 \mathrm{H}), 1.60(\mathrm{~s}, 9 \mathrm{H}) ;{ }^{13} \mathrm{C} \mathrm{NMR}\left(125 \mathrm{MHz}, \mathrm{CDCl}_{3}\right) \delta$ 153.6, 138.0, $132.3,128.8,128.0,125.8,114.1,83.7,82.4,81.7,36.4,35.6,28.6,21.0 ;$ HRMS (FAB, $m / z$ ) calcd for $(\mathrm{M}+\mathrm{H})^{+} \mathrm{C}_{13} \mathrm{H}_{17} \mathrm{FNO}_{3} 254.1192$, found 254.1194. N-Boc 5-cyano-2-hydroxyindoline (2e): 
white solid; mp 118-120 ${ }^{\circ} \mathrm{C}$; IR (KBr, cm ${ }^{-1}$ ) 3424, 3000, 2975, 2234, 1711, 1610; ${ }^{1} \mathrm{H}$ NMR (500 $\left.\mathrm{MHz} \mathrm{CDCl}_{3}\right) \delta 7.89(\mathrm{~s}(\mathrm{br}), 0.2 \mathrm{H}), 7.43-7.51(\mathrm{~m}, 2.5 \mathrm{H}), 6.04(\mathrm{~s}(\mathrm{br}), 1 \mathrm{H}), 4.13(\mathrm{~s}(\mathrm{br}), 0.4 \mathrm{H})$, $3.36(\mathrm{~m}, 1.3 \mathrm{H}), 3.02(\mathrm{~d}, J=17.0 \mathrm{~Hz}, 1 \mathrm{H}), 1.62(\mathrm{~s}, 9 \mathrm{H}) ;{ }^{13} \mathrm{C} \mathrm{NMR}\left(125 \mathrm{MHz}, \mathrm{CDCl}_{3}\right) \delta 159.8$, $158.2,153.3,151.3,137.2,136.5,130.7,129.9,115.0,113.9,113.7,112.5,112.3,112.2,112.0,83.8$, 83.6, 82.8, 82.0, 36.3, 35.6, 29.8, 28.5; HRMS (FAB, $m / z)$ calcd for $(\mathrm{M}+\mathrm{H})^{+} \mathrm{C}_{14} \mathrm{H}_{17} \mathrm{~N}_{2} \mathrm{O}_{3}$ 261.1239, found 261.1246. N-Boc 2-hydroxy-5-methoxycarbonylindoline (2f): colorless oil; IR

(neat, $\mathrm{cm}^{-1}$ ) 3439, 2983, 2951, 1703, 1613; ${ }^{1} \mathrm{H}$ NMR $\left(500 \mathrm{MHz}, \mathrm{CDCl}_{3}\right) \delta 7.85-7.93(\mathrm{~m}, 2.5 \mathrm{H})$, $7.43(\mathrm{~s}(\mathrm{br}), 0.5 \mathrm{H}), 6.05(\mathrm{~s}(\mathrm{br}), 1 \mathrm{H}), 4.05(\mathrm{~s}(\mathrm{br}), 0.5 \mathrm{H}), 3.89(\mathrm{~s}, 3 \mathrm{H}), 3.37(\mathrm{~m}, 1.2 \mathrm{H}), 3.02(\mathrm{~d}, J=$ $17.2 \mathrm{~Hz}, 1 \mathrm{H}), 1.62(\mathrm{~s}, 9 \mathrm{H}) ;{ }^{13} \mathrm{C}$ NMR $\left(125 \mathrm{MHz}, \mathrm{CDCl}_{3}\right) \delta 166.9,153.0,144.0,130.2,128.6$, $126.3,124.5,113.7,84.0,83.4,52.0,35.8,35.0,28.4$; HRMS (FAB, $m / z)$ calcd for $(\mathrm{M}+\mathrm{H})^{+}$ $\mathrm{C}_{15} \mathrm{H}_{20} \mathrm{NO}_{5}$ 294.1341, found 294.1315. N-Boc 2-hydroxy-3-methylindoline (2g): white solid;

mp 84-86 ${ }^{\circ} \mathrm{C}$; IR $\left(\mathrm{KBr}, \mathrm{cm}^{-1}\right)$ 3466, 3114, 1692; ${ }^{1} \mathrm{H}$ NMR $\left(500 \mathrm{MHz}, \mathrm{CDCl}_{3}\right) \delta 7.79$ (s (br), $0.2 \mathrm{H}), 7.40(\mathrm{~s}(\mathrm{br}), 0.5 \mathrm{H}), 7.23-7.12(\mathrm{~m}, 2 \mathrm{H}), 7.00(\mathrm{t}, J=7.4 \mathrm{~Hz}, 1 \mathrm{H}), 5.52(\mathrm{~m}(\mathrm{br}), 1 \mathrm{H}), 4.07(\mathrm{~s}$, $0.4 \mathrm{H}), 3.30-3.17(\mathrm{~m}, 1.2 \mathrm{H}), 1.62(\mathrm{~s}, 9 \mathrm{H}), 1.32(\mathrm{~m}, 3 \mathrm{H}) ;{ }^{13} \mathrm{C} \mathrm{NMR}\left(125 \mathrm{MHz}, \mathrm{CDCl}_{3}\right) \delta 153.8$, 139.7, 134.2, 127.9, 124.2, 122.9, 114.4, 100.1, 90.8, 42.3, 28.6, 19.3; HRMS (FAB, $m / z$ ) calcd for $(\mathrm{M}+\mathrm{H})^{+} \mathrm{C}_{14} \mathrm{H}_{20} \mathrm{NO}_{3} 250.1443$, found 250.1439. N-Boc 2-methoxyindoline (3): colorless

oil; IR (neat, $\mathrm{cm}^{-1}$ ) 2976, 2929, 1702, 1604; ${ }^{1} \mathrm{H}$ NMR (500 MHz, $\left.\mathrm{CDCl}_{3}\right) \delta 7.80$ (s (br), 0.2H), $7.51(\mathrm{~s}(\mathrm{br}), 0.2 \mathrm{H}), 7.23-7.15(\mathrm{~m}, 2 \mathrm{H}), 6.98(\mathrm{t}, J=7.5 \mathrm{~Hz}, 1 \mathrm{H}), 5.66(\mathrm{~m}(\mathrm{br}), 1 \mathrm{H}), 3.42(\mathrm{~s}, 3 \mathrm{H})$, $3.27(\mathrm{~m}, 1 \mathrm{H}), 2.91(\mathrm{~d}, J=17.5 \mathrm{~Hz}, 1 \mathrm{H}), 1.59(\mathrm{~s}, 9 \mathrm{H}) ;{ }^{13} \mathrm{C} \mathrm{NMR}\left(125 \mathrm{MHz}, \mathrm{CDCl}_{3}\right) \delta 152.6$, $140.9,129.6,127.3,124.6,122.9,115.8,89.8,81.4,55.3,35.8,28.4$; HRMS (FAB, $m / z)$ calcd for $(\mathrm{M}+\mathrm{H})^{+} \mathrm{C}_{14} \mathrm{H}_{20} \mathrm{NO}_{3} 250.1443$, found 250.1420. N-Boc 2-ethoxyindoline (4): colorless oil;

IR (neat, $\mathrm{cm}^{-1}$ ) 2950, 1690, 1615; ${ }^{1} \mathrm{H}$ NMR $\left(500 \mathrm{MHz}, \mathrm{CDCl}_{3}\right) \delta 7.82-7.37$ (m(br), 0.6H), $7.23-7.15(\mathrm{~m}, 2 \mathrm{H}), 6.98(\mathrm{t}, J=7.5 \mathrm{~Hz}, 1 \mathrm{H}), 5.71(\mathrm{~m}(\mathrm{br}), 1 \mathrm{H}), 3.71-3.65(\mathrm{~m}(\mathrm{br}), 2 \mathrm{H}), 3.27$ $(\mathrm{m}, 1 \mathrm{H}), 2.93(\mathrm{~d}, J=17.3 \mathrm{~Hz}, 1 \mathrm{H}), 1.59(\mathrm{~s}, 9 \mathrm{H}), 1.19(\mathrm{t}, J=7.2 \mathrm{~Hz}, 3 \mathrm{H}) ;{ }^{13} \mathrm{C} \mathrm{NMR}(125 \mathrm{MHz}$, $\left.\mathrm{CDCl}_{3}\right) \delta 127.3,122.8,116.0,88.7,36.2,29.7,28.4,15.4,14.1$; HRMS (FAB, $m / z$ ) calcd for $(\mathrm{M}+\mathrm{H})^{+} \mathrm{C}_{15} \mathrm{H}_{22} \mathrm{NO}_{3}$ 264.1600, found 264.1599. N-Boc 2-cyanoindoline (5): white solid; $\mathrm{mp}$

111-112 ${ }^{\circ} \mathrm{C}$; IR $\left(\mathrm{KBr}, \mathrm{cm}^{-1}\right)$ 2981, 2934, 2230, 1697, 1603; ${ }^{1} \mathrm{H}$ NMR $\left(500 \mathrm{MHz}, \mathrm{CDCl}_{3}\right) \delta 7.85$ (s (br), 0.5H), $7.24(\mathrm{~m}, 1 \mathrm{H}), 7.18(\mathrm{~d}, J=7.5 \mathrm{~Hz}, 1 \mathrm{H}), 7.02(\mathrm{t}, J=7.5 \mathrm{~Hz}, 1 \mathrm{H}), 5.09(\mathrm{~s}(\mathrm{br}), 1 \mathrm{H})$, 3.54-3.59 (m, 1H), $3.39(\mathrm{~d}, J=16.0 \mathrm{~Hz}, 1 \mathrm{H}), 1.61(\mathrm{~s}, 9 \mathrm{H}) ;{ }^{13} \mathrm{C} \mathrm{NMR}\left(125 \mathrm{MHz}, \mathrm{CDCl}_{3}\right) \delta$ $151.9,141.0,128.5,124.6,123.2,118.7,115.1,83.2,48.6,33.6,28.2 ;$ HRMS (FAB, $m / z)$ calcd for $(\mathrm{M}+\mathrm{H})^{+} \mathrm{C}_{14} \mathrm{H}_{17} \mathrm{~N}_{2} \mathrm{O}_{2}$ 245.1290, found 245.1269. Major diastereomer of 7: white solid; mp 71-73 ${ }^{\circ} \mathrm{C}$; IR $\left(\mathrm{KBr}, \mathrm{cm}^{-1}\right)$ 3347, 3356, 2974, 2951, 1739, 1712, 1693, 1602, 1509; ${ }^{1} \mathrm{H}$ NMR $\left(500 \mathrm{MHz}, \mathrm{CDCl}_{3}\right) \delta 7.82(\mathrm{~s}(\mathrm{br}), 0.2 \mathrm{H}), 7.42(\mathrm{~s}(\mathrm{br}), 0.5 \mathrm{H}), 7.33-7.32(\mathrm{~m}, 1 \mathrm{H}), 7.24-7.22(\mathrm{~m}$, $1 \mathrm{H}), 7.02(\mathrm{~m}, 1 \mathrm{H}), 5.63(\mathrm{~s}, 1 \mathrm{H}), 5.18(\mathrm{~m}, 1 \mathrm{H}), 4.56(\mathrm{~s}, 1 \mathrm{H}), 4.07(\mathrm{~s}(\mathrm{br}), 0.5 \mathrm{H}), 3.72(\mathrm{~s}, 3 \mathrm{H}), 3.22$ $(\mathrm{s}, 1.2 \mathrm{H}), 1.98(\mathrm{~m}, 2 \mathrm{H}), 1.61(\mathrm{~s}, 9 \mathrm{H}), 1.47(\mathrm{~s}, 9 \mathrm{H}) ;{ }^{13} \mathrm{C} \mathrm{NMR}\left(125 \mathrm{MHz}, \mathrm{CDCl}_{3}\right) \delta$ 173.0, 155.4, 153.4, 151.3, 140.5, 139.8, 131.5, 130.9, 128.2, 125.4, 125.0, 123.0, 114.6, 89.1, 88.7, 82.8, 82.1, 80.2, 52.5, 51.3, 45.0, 43.9, 36.7, 28.4, 28.3; HRMS (FAB, $m / z)$ calcd for $(\mathrm{M}+\mathrm{H})^{+} \mathrm{C}_{22} \mathrm{H}_{33} \mathrm{~N}_{2} \mathrm{O}_{7}$ 437.2288, found 437.2302. Minor diastereomer of 7: white solid; $\mathrm{mp} 71-73^{\circ} \mathrm{C}$; $\mathrm{IR}\left(\mathrm{KBr}, \mathrm{cm}^{-1}\right)$

3361, 3324, 2974, 2932, 1739, 1708, 1693, 1602, 1509; ${ }^{1} \mathrm{H}$ NMR (500 MHz, CDCl $) \delta 7.80$ (s (br), 0.2H), $7.42(\mathrm{~s}(\mathrm{br}), 0.3 \mathrm{H}), 7.22-7.15(\mathrm{~m}, 2 \mathrm{H}), 6.99(\mathrm{~m}, 1 \mathrm{H}), 5.73(\mathrm{~s}(\mathrm{br}), 0.6 \mathrm{H}), 5.33(\mathrm{~m}$, $0.7 \mathrm{H}), 4.55(\mathrm{~m}, 1 \mathrm{H}), 3.75(\mathrm{~s}, 3 \mathrm{H}), 3.39(\mathrm{~s}, 0.1 \mathrm{H}), 3.15(\mathrm{~m}, 0.9 \mathrm{H}), 2.36-1.96(\mathrm{~m}, 2 \mathrm{H}), 1.62(\mathrm{~s}$, 9H), $1.46(\mathrm{~s}, 9 \mathrm{H}) ;{ }^{13} \mathrm{C}$ NMR $\left(125 \mathrm{MHz}, \mathrm{CDCl}_{3}\right) \delta 172.7,155.7,140.1,131.4,128.2,124.4,122.8$, 114.6, 88.1, 80.5, 80.1, 52.6, 52.4, 51.7, 37.1, 28.5, 28.3; HRMS (FAB, $m / z)$ calcd for $(\mathrm{M}+\mathrm{H})^{+}$ $\mathrm{C}_{22} \mathrm{H}_{33} \mathrm{~N}_{2} \mathrm{O}_{7}$ 437.2288, found 437.2302.

\section{Results and Discussion}

Initially, we attempted to optimize the photochemical reaction conditions using $N$-Boc indole 1a (Boc $=t$-butoxycarbonyl) and various organic photoredox catalysts (Table 1). Irradiation (100 W high-pressure mercury lamp with a Pyrex glass filter; $\lambda>280 \mathrm{~nm}$ ) of 1a $(20 \mathrm{mM})$ in aqueous acetonitrile $\left(\mathrm{CH}_{3} \mathrm{CN} / \mathrm{H}_{2} \mathrm{O}=9: 1, v / v\right)$ containing Phen $(20 \mathrm{mM})$ and 1,4-DCB $(20 \mathrm{mM})$ in an argon atmosphere for $6 \mathrm{~h}$ at room temperature afforded $\mathrm{N}$ - 
Boc 2-hydroxyindoline $2 \mathrm{a}(25 \%)$ as a racemic mixture, $60 \%$ recovered $1 \mathrm{a}$, along with the near-quantitative recovery of Phen and 1,4-DCB (entry 1 ). Decreasing the concentration of 1a $(10 \mathrm{mM})$ and increasing those of Phen and 1,4-DCB $(30 \mathrm{mM})$ improved the yield of $2 \mathbf{a}$ (entries 2 and 3). The addition of $\mathrm{NaOH}(20 \mathrm{mM})$ as a nucleophile and prolonged irradiation time $(12 \mathrm{~h})$ increased the yield of $2 \mathbf{a}(73 \%$, entry 4$)$. These results indicated that to increase the efficiency of the photoreaction, a high concentration of the photoredox catalyst, long irradiation time, and a strong nucleophile were required because of the difficulty in dearomatizing 1a via the nucleophilic addition. In the absence of either light, Phen, 1,4-DCB, the photoinduced dearomatization of $1 \mathrm{a}$ did not proceed at all and almost recovered 1a $(99 \%, 91 \%, 93 \%$, entries $5-7)$. The influence of various photoredox catalysts in the photoreaction was evaluated (entries 8-12), and the use of naphthalene (NP), 1-methylnaphthalene (1-MNP), biphenyl (BP), 1,3-dicyanobenzene (1,3-DCB), 1,2dicyanobenzene (1,2-DCB), and 1,4-dicyanonaphthalene (1,4-DCN) instead of Phen and 1,4-DCB resulted in decreased product yields. Specifically, a combination of BP and 1,4DCN accelerated the photoreaction, with $1 \mathrm{a}$ being completely consumed after $12 \mathrm{~h}$, and decreased the yield of $\mathbf{2 a}$, indicating that a secondary photoreaction of $\mathbf{2 a}$ had occurred as a result of the higher oxidation potential of BP compared to that of Phen (oxidation potential vs. SCE in acetonitrile: BP $+1.95 \mathrm{~V}$ [46], Phen $+1.50 \mathrm{~V}$ [47]) (entry 9). In fact, a shorter irradiation time $(8 \mathrm{~h}$ ) improved the yield of $\mathbf{2 a}$ (entry 13). Solvent screening indicated that aqueous $\mathrm{CH}_{3} \mathrm{CN}$ was the optimal solvent for the photoreaction (entries 14 and 15). Although catalytic amounts of Phen and 1,4-DCB (5 mM) accomplished photoredox catalysis, the yield of $\mathbf{2 a}$ was moderate after $12 \mathrm{~h}$ of irradiation time ( $43 \%$, entry 16) due to the low efficiency of the photoreaction. Thus, a high concentration $(30 \mathrm{mM})$ of Phen /1,4-DCB, a low concentration (10 mM) of $1 \mathrm{a}$, and a long irradiation time $(12 \mathrm{~h})$ in the presence of $\mathrm{NaOH}(10 \mathrm{mM})$ as a strong nucleophile provided 2a in an almost quantitative yield (98\%, entry 17$)$.

Table 1. Optimization of the conditions for PET-promoted nucleophilic addition to 1a.

\begin{tabular}{|c|c|c|c|c|}
\hline & 1a (20 mM) & $\overbrace{\mathrm{Boc}}^{\mathrm{Ba}}$ & & \\
\hline Entry & Photocatalysts and $\mathrm{NaOH}$ & Irradiation Time $/ \mathrm{h}$ & Yield of $2 a / \%$ & Recovery of $1 \mathrm{a} / \%$ \\
\hline 1 & Phen (20 mM), 1,4-DCB (20 mM) & 6 & 25 & 60 \\
\hline $2^{\mathrm{a}}$ & Phen (20 mM), 1,4-DCB (20 mM) & 6 & 33 & 50 \\
\hline $3^{a}$ & Phen $(30 \mathrm{mM}), 1,4-\mathrm{DCB}(30 \mathrm{mM})$ & 6 & 47 & 44 \\
\hline 4 & Phen (20 mM), 1,4-DCB (20 mM), NaOH (20 mM) & 12 & 73 & 8 \\
\hline $5^{b}$ & Phen (20 mM), 1,4-DCB (20 mM), NaOH (20 mM) & 12 & 0 & 99 \\
\hline 6 & 1,4-DCB $(20 \mathrm{mM}), \mathrm{NaOH}(20 \mathrm{mM})$ & 12 & 0 & 91 \\
\hline 7 & Phen $(20 \mathrm{mM}), \mathrm{NaOH}(20 \mathrm{mM})$ & 12 & 0 & 93 \\
\hline 8 & NP (20 mM), 1,4-DCB (20 mM), NaOH (20 mM) & 12 & 51 & 26 \\
\hline 9 & 1-MNP (20 mM), 1,4-DCB (20 mM), NaOH (20 mM) & 12 & 33 & 39 \\
\hline 10 & Phen $(20 \mathrm{mM}), 1,3-\mathrm{DCB}(20 \mathrm{mM}), \mathrm{NaOH}(20 \mathrm{mM})$ & 12 & 60 & 14 \\
\hline 11 & Phen $(20 \mathrm{mM}), 1,2-\mathrm{DCB}(20 \mathrm{mM}), \mathrm{NaOH}(20 \mathrm{mM})$ & 12 & 62 & 10 \\
\hline 12 & $\mathrm{BP}(20 \mathrm{mM}), 1,4-\mathrm{DCN}(20 \mathrm{mM}), \mathrm{NaOH}(20 \mathrm{mM})$ & 12 & 40 & 0 \\
\hline 13 & BP $(20 \mathrm{mM}), 1,4-\mathrm{DCN}(20 \mathrm{mM}), \mathrm{NaOH}(20 \mathrm{mM})$ & 8 & 70 & 0 \\
\hline $14^{\mathrm{c}}$ & Phen (20 mM), 1,4-DCB (20 mM), NaOH (20 mM) & 12 & 10 & 66 \\
\hline $15^{d}$ & Phen (20 mM), 1,4-DCB (20 mM), NaOH (20 mM) & 12 & 55 & 39 \\
\hline 16 & Phen (5 mM), 1,4-DCB (5 mM), NaOH (20 mM) & 12 & 43 & 33 \\
\hline $17^{\mathrm{a}}$ & Phen (30 mM), 1,4-DCB (30 mM), NaOH (10 mM) & 12 & 98 & trace \\
\hline
\end{tabular}

${ }^{\mathrm{a}}[\mathbf{1 a}]=10 \mathrm{mM} \cdot{ }^{\mathrm{b}}$ In the absence of light. ${ }^{\mathrm{c}}$ In DMF $/ \mathrm{H}_{2} \mathrm{O}=9: 1, v / v .{ }^{\mathrm{d}}$ In THF $/ \mathrm{H}_{2} \mathrm{O}=9: 1, v / v$. 
To elucidate the role of the nucleophile, photoreactions of 1a were performed with a variety of nucleophiles in anhydrous $\mathrm{CH}_{3} \mathrm{CN}$ (Scheme 2). Employing stronger nucleophiles, such as $\mathrm{NaOCH}_{3}$ or $\mathrm{NaOCH}_{2} \mathrm{CH}_{3}$, led to low yields of addition products $3(28 \%)$ and 4 $(16 \%)$, respectively, within a shorter irradiation time $(3 \mathrm{~h})$, which was likely due to the occurrence of side-reactions and secondary photoreactions. In the absence of $\mathrm{NaOCH}_{3}$ or $\mathrm{NaOCH}_{2} \mathrm{CH}_{3}$, the use of $\mathrm{CH}_{3} \mathrm{CN} / \mathrm{CH}_{3} \mathrm{OH}$ or $\mathrm{CH}_{3} \mathrm{CN} / \mathrm{CH}_{3} \mathrm{CH}_{2} \mathrm{OH}$ as a solvent did not improve the yields of 3 or 4 . In the case of $\mathrm{KO} t-\mathrm{Bu}$ in $\mathrm{CH}_{3} \mathrm{CN} / t-\mathrm{BuOH}=9: 1$, the corresponding addition product was not observed. On the other hand, $\mathrm{NaCN}$, a weaker nucleophile, afforded adduct 5 , an intermediate for the preparation of a cardioprotective drug [48], at a moderate yield (42\%), and higher concentrations of $\mathrm{NaCN}$ (30 and $50 \mathrm{mM}$ ) resulted in an increased yield of 5 ( $70 \%$ and $72 \%$, respectively). Thus, in addition to $\mathrm{C}-\mathrm{O}$ bond formation at the 2-position of indoline from indole, $\mathrm{C}-\mathrm{C}$ bond formation using $\mathrm{NaCN}$ as a nucleophile was achieved.

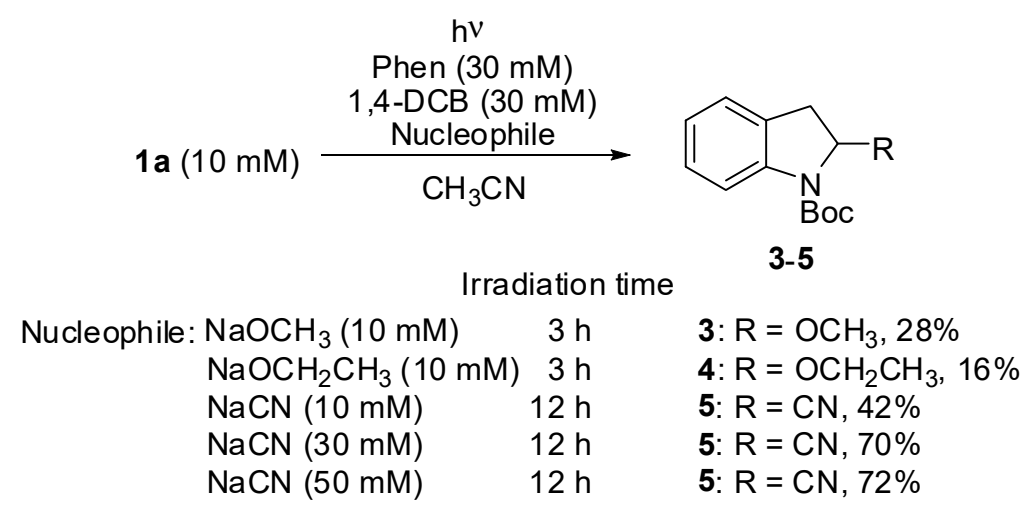

Scheme 2. Photoreaction of 1 a with various nucleophiles.

Next, the scope and limitations of indole 1 in the photoreaction were explored (Figure 1). The photoreaction of $\mathrm{N}$-Boc 5-methylindole $\mathbf{1} \mathbf{b}$ under the optimized photochemical conditions produced the corresponding indoline $\mathbf{2 b}$ at a $76 \%$ yield, whereas $\mathrm{N}$-Boc 5-methoxylindole $1 \mathrm{c}$ with increased electron-donating capacity did not afford the recovery of $\mathbf{2 c}$, and $\mathbf{1 c}$ was recovered $(79 \%)$, which was probably because the enhanced electron-donating capacity of $\mathbf{1 c}$ disturbed the PET between Phen and 1,4-DCB. When electron-deficient indoles, such as $\mathrm{N}$-Boc 5-fluorolindole $\mathbf{1 d}, \mathrm{N}$-Boc 5-cyanolindole $\mathbf{1 e}$, and $\mathrm{N}$-Boc 5-methoxycarbonylindole 1f, were subjected to the optimized photochemical conditions, low yields of $\mathbf{2} \mathbf{d}-\mathbf{f}$ (trace, trace, and $10 \%)$ and high recoveries of $\mathbf{1 d}-\mathbf{f}(74 \%, 93 \%$, and $69 \%$ ), respectively, were observed, indicating that the radical cation of Phen did not efficiently oxidize these electron-deficient indoles. The use of the BP/1,4-DCN system with enhanced oxidizing power provided moderate yields $(54 \%, 57 \%$, and $60 \%$ ) of dearomatized addition products $\mathbf{2 d}-\mathbf{f}$, respectively. In addition, obtaining a moderate yield of $2 \mathbf{g}(67 \%)$ from the photoreaction of $N$-Boc 3-methylindole $1 \mathrm{~g}$ with Phen/1,4-DCB within a shorter irradiation time $(6 \mathrm{~h})$ indicated that the presence of an alkyl group at the 3-position led to an increase in photochemical reactivity, but a prolonged irradiation time $(12 \mathrm{~h})$ decreased the yield to $2 \mathrm{~g}(28 \%)$, owing to secondary photoreactions. Thus, the efficiency of a dearomative addition to 1 via PET is strongly dependent on electronic factors, that is, the donor and acceptor ability of the substituents at the 3- and 5-positons, and suitable selection of both the photoredox catalyst and irradiation time was required to increase the product yield. 

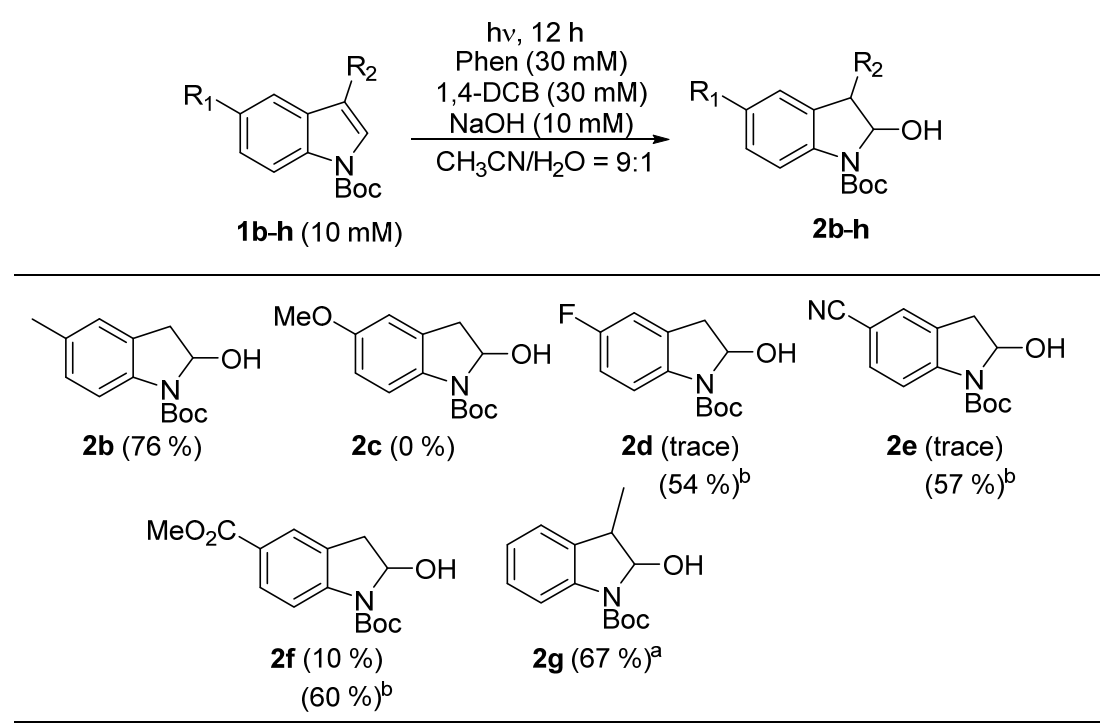

Figure 1. Scope and limitation of indole 1 in the photoreaction using Phen/1,4-DCB or BP/1,4-DCN. ${ }^{\mathrm{a}}$ Irradiation time was $6 \mathrm{~h} .{ }^{\mathrm{b}} \mathrm{BP} / 1,4-\mathrm{DCN}$ were used as the photocatalyst.

Finally, the reaction of tryptophan derivative 6 was conducted under optimized photochemical conditions. In the absence of $\mathrm{NaOH}, 6$ furnished the dearomatized addition product 7 as a diastereomeric mixture (major:minor diastereomer $=1.15: 1$ ) in $35 \%$ yield (Scheme 3). When $\mathrm{NaOH}$ was added or when BP/1,4-DCN was used instead of Phen/1,4$\mathrm{DCB}, 7$ was not observed, which was probably because side-reactions, such as hydrolysis, or because secondary photoreactions occurred. Photoinduced nucleophilic dearomatization of histidine derivative 8 bearing an imidazole was attempted, but the photoreaction did not proceed at all, and $\mathbf{8}$ was quantitatively recovered. In the cases of phenylalanine and tyrosine derivatives bearing aromatic rings, a similar photoreaction entailing the formation of the corresponding radical cations via PET afforded debenzylated products, as reported by us [49]. Thus, in amino acids, the PET reaction pathway is strongly dependent on the structure of the amino acids bearing aromatic rings, and the formation of a radical tryptophan cation in an aqueous solvent furnished the dearomatized adduct.<smiles>CC(C)(C)OC(=O)NC(Cc1c[nH]c2ccccc12)C(=O)OCc1ccccc1</smiles>
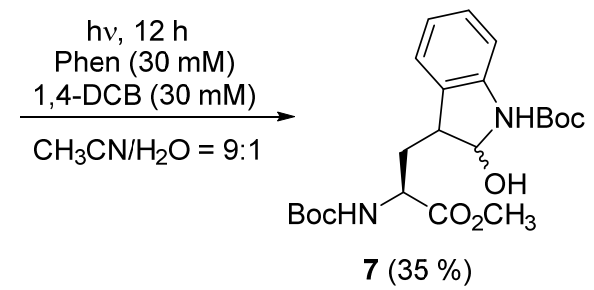<smiles>COC(=O)NC(Cc1cnccn1)C(=O)OCc1ccccc1</smiles>

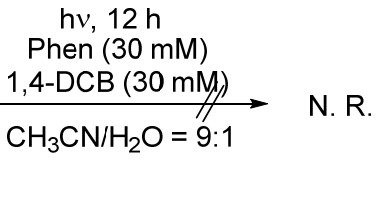

Scheme 3. Photoreactions of tryptophan derivative 6 and histidine derivative 8 using Phen/1,4-DCB.

From the aforementioned results, a plausible mechanism for the photoinduced dearomative nucleophilic addition to 1a is shown in Scheme 4. First, PET between the excited state of Phen and 1,4-DCB initiated by light absorption (mainly $313 \mathrm{~nm}$ ) generates a Phen radical cation and 1,4-DCB radical anion. A second electron transfer between $1 \mathbf{a}$ and the 
radical cation of Phen forms the radical cation of $\mathbf{1 a}$ and Phen, and it is surmised from the oxidation potential of Phen $(+1.50 \mathrm{~V}$ vs. SCE in acetonitrile) and 1a (indole: $+1.16 \mathrm{~V}$ vs SCE in acetonitrile [50]) that the electron transfer is an exothermic process. However, the efficiency of the electron transfer between the radical cation of Phen and indoles having electron-withdrawing substituents, as in the case of $\mathbf{1 d - f}$, which was relatively low, and therefore, the addition products were not efficiently formed. In these cases, BP was more suitable as the photoredox catalyst due to the enhanced oxidizing ability of its radical cation. The nucleophilic addition to the radical cation of $\mathbf{1 a}$ forms the corresponding benzyl radical, and the sequential back electron transfer (BET) from the radical anion of 1,4-DCB to the benzyl radical generates a carbanion; protonation follows to yield $2 \mathbf{a}$. The efficiency of the formation of 2a was relatively low, probably because the BET rates between the radical ion pairs (Phen/DCB or 1a/DCB radical ion pairs) were faster than the dearomative nucleophilic addition to the radical cation of 1a. Thus, both the sufficiently high photoredox catalyst concentrations and the high nucleophilicity of the nucleophile were required for the efficient formation of $\mathbf{2} \mathbf{a}$ whilst avoiding the occurrence of the side-reactions and secondary photoreactions.

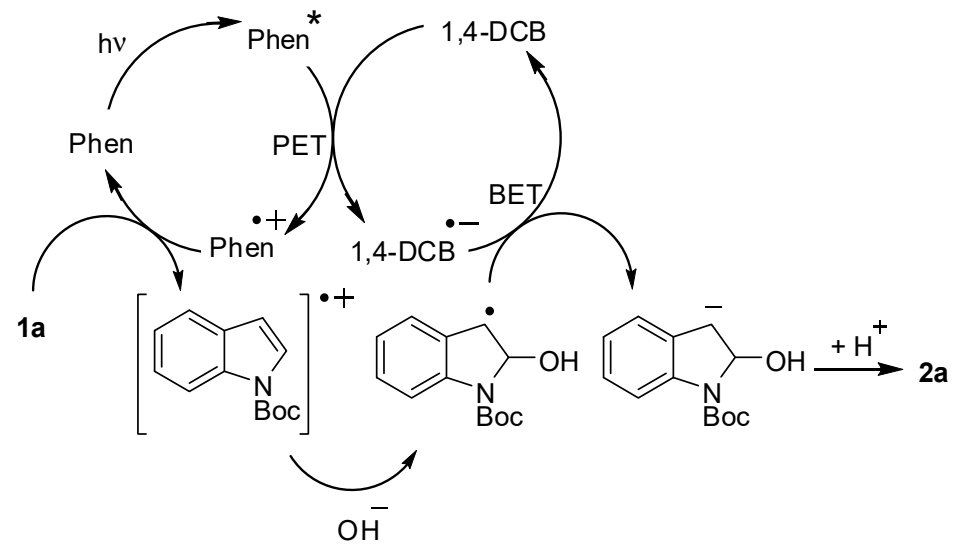

Scheme 4. Plausible mechanism for the photoreaction.

\section{Conclusions}

In conclusion, a new method for the preparation of 2-substituted indolines via a nucleophilic dearomative addition to indoles was achieved using organic photocatalysts (Phen/1,4-DCB or BP/1,4-DCN) under mild conditions. The efficiency of the photoreaction was strongly dependent on the electronic nature of the indole and the suitable selection of the photoredox catalyst. Further investigations into the application of this methodology to the modification of tryptophan-containing peptides are underway.

Supplementary Materials: The following are available onlineat https://www.mdpi.com/article/10 $.3390 /$ photochem $1030027 / \mathrm{s} 1,{ }^{1} \mathrm{H}$ and ${ }^{13} \mathrm{C}$ NMR spectra of $\mathbf{2 a , b}, \mathbf{d}-\mathbf{g}, \mathbf{3}, \mathbf{4}, \mathbf{5}, \mathbf{7}$.

Author Contributions: Conceptualization, writing, supervision, and funding acquisition Y.Y.; investigation, Y.T., T.I., T.M. (Taisei Mizuno) and K.M.; data curation, Y.T., T.I. and Y.N.; analysis, C.S., M.Y. and T.M. (Toshio Morita). All authors have read and agreed to the published version of the manuscript.

Funding: This work was partially supported by the Japan Society for the Promotion of Science (JSPS), Grant-in-Aid no. 20K05510, for scientific research, and the Asahi Glass Foundation.

Institutional Review Board Statement: Not applicable.

Informed Consent Statement: Not applicable.

Data Availability Statement: The data presented in this study are available in Supplementary Material.

Conflicts of Interest: The authors declare no conflict of interest. 


\section{References}

1. Hayashi, M.; Kim, Y.-P.; Takamatsu, S.; Enomoto, A.; Shinose, M.; Takahashi, Y.; Tanaka, H.; Komiyama, K.; Ohmura, S.J. Madindoline, a novel inhibitor of IL-6 activity from Streptomyces sp. K93-0711. I. Taxonomy, fermentation, isolation and biological activities. J. Antibiot. 1996, 49, 1091-1095. [CrossRef]

2. Hirose, T.; Sunazuka, T.; Yamamoto, D.; Kojima, N.; Shirahata, T.; Harigaya, Y.; Kuwajima, I.; Ohmura, S. Determination of the absolute stereochemistry and asymmetric total synthesis of madindolines A and B: A practical improvement to a secondgeneration approach from the first-generation. Tetrahedron 2005, 61, 6015-6039. [CrossRef]

3. Sunazuka, T.; Hirose, T.; Ohmura, S. Total synthesis of madindolines, potent selective inhibitors, novel bioactive microbial metabolites. J. Synth. Org. Chem. Jpn. 2005, 63, 1090-1101. [CrossRef]

4. Subramaniam, G.; Hiraku, O.; Hayashi, M.; Koyano, T.; Komiyama, K.; Kam, T.-S. Biologically active aspidofractinine alkaloids from Kopsia singapurensis. J. Nat. Prod. 2007, 70, 1783-1789. [CrossRef]

5. Yousuf, Z.; Richards, A.K.; Dwyer, A.N.; Linclau, B.; Harrowven, D.C. The development of a short route to the API ropinirole hydrochloride. Org. Biomol. Chem. 2015, 13, 10532-10539. [CrossRef]

6. Roche, S.P.; Tendoung, J.-J.Y.; Tréguier, B. Advances in dearomatization strategies of indoles. Tetrahedron 2015, 71, 3549-3591. [CrossRef]

7. Zheng, C.; You, S.L. Catalytic asymmetric dearomatization (CADA) reaction-enabled total synthesis of indole-based natural products. Nat. Prod. Rep. 2019, 36, 1589-1605. [CrossRef] [PubMed]

8. Chen, J.-B.; Jia, Y.-X. Recent progress in transition-metal-catalyzed enantioselective indole functionalizations. Org. Biomol. Chem. 2017, 15, 3550-3567. [CrossRef] [PubMed]

9. Zhang, D.; Song, H.; Qin, Y. Total synthesis of indoline alkaloids: A cyclopropanation strategy. Acc. Chem. Res. 2011, 44, 447-457. [CrossRef]

10. Liu, C.; Zhang, W.; You, S.-L. Copper(I)-catalyzed cascade dearomatization of 2-substituted tryptophols with iodonium Salts. Org. Lett. 2012, 14, 4525-4527. [CrossRef]

11. Liu, C.; Zhang, W.; Dai, L.-X.; You, S.-L. Cascade dearomatization of N-substituted tryptophols via Lewis acid-catalyzed Michael reactions. Org. Biomol. Chem. 2012, 10, 7177-7183. [CrossRef]

12. Zhang, X.; Yang, Z.-P.; Liu, C.; You, S.-L. Ru-catalyzed intermolecular dearomatization reaction of indoles with allylic alcohols. Chem. Sci. 2013, 4, 3239-3243. [CrossRef]

13. Ye, Z.; Rawal, V.H. Palladium-catalyzed C3-benzylation of indoles. J. Am. Chem. Soc. 2012, 134, 111-114.

14. Liu, H.; Jiang, G.; Pan, X.; Wan, X.; Lai, Y.; Ma, D.; Weiqing, X. Highly asymmetric bromocyclization of tryptophol: Unexpected accelerating effect of DABCO-derived bromine complex. Org. Lett. 2014, 16, 1908-1911. [CrossRef] [PubMed]

15. Jiang, S.-Z.; Zeng, X.-Y.; Liang, X.; Lei, T.; Wei, K.; Yang, Y.-R. Iridium-catalyzed enantioselective indole cyclization: Application to the total synthesis and absolute stereochemical assignment of (-)-Aspidophylline A. Angew. Chem. Int. Ed. 2016, 55, 4044-4048. [CrossRef]

16. Boal, B.W.; Schammel, A.W.; Grag, N.K. An interrupted Fischer indolization approach toward fused indoline-containing natural products. Org. Lett. 2009, 11, 3458-3461. [CrossRef] [PubMed]

17. Schammel, A.W.; Boal, B.W.; Zu, L.; Mesganaw, T.; Grag, N.K. Copper(I)-catalyzed cascade dearomatization of 2-substituted tryptophols with arylidonium salts. Tetrahedron 2010, 66, 4687-4695. [CrossRef]

18. Clark, R.D.; Muchowski, J.M.; Fisher, L.E.; Flippin, L.A.; Repke, D.B.; Souchet, M. Preparation of indoles and oxindoles from N-(tert-butoxycarbonyl)-2-alkylanilines. Synthesis 1991, 1991, 871-878. [CrossRef]

19. Chiou, W.-H.; Kao, C.-L.; Tsai, J.-C.; Chang, Y.-M. Domino Rh-catalyzed hydroformylation-double cyclization of $o$-amino cinnamyl derivatives: Applications to the formal total syntheses of physostigmine and physovenine. Chem. Commun. 2013, 49, 8232-8234. [CrossRef]

20. Nambu, H.; Hirota, W.; Fukumoto, M.; Tamura, T.; Yakura, T. An efficient route to highly substituted indoles via tetrahydroindol$4(5 \mathrm{H})$-one intermediates produced by ring-opening cyclization of spirocyclopropanes with amines. Chem. Eur. J. 2017, 23, 16799-16805. [CrossRef]

21. Review, S.; Yoshimi, Y. Photoinduced electron transfer-promoted decarboxylative radical reactions of aliphatic carboxylic acids by organic photoredox system. J. Photochem. Photobiol. A 2017, 342, 116-130.

22. Yoshimi, Y.; Itou, T.; Hatanaka, M. Decarboxylative reduction of free aliphatic carboxylic acid by photogenerated cation radical. Chem. Commun. 2007, 48, 5244-5246. [CrossRef]

23. Itou, T.; Yoshimi, Y.; Morita, T.; Tokunaga, Y.; Hatanaka, M. Decarboxylative photosubstitution of dicyanobenzenes with aliphatic carboxylate ions. Tetrahedron 2009, 65, 263-269. [CrossRef]

24. Yoshimi, Y.; Masuda, M.; Mizunashi, T.; Nishikawa, K.; Maeda, K.; Koshida, N.; Itou, T.; Morita, T.; Hatanaka, M. Inter- and intramolecular addition reactions of electron-deficient alkenes with alkyl radicals, generated by SET-photochemical decarboxylation of carboxylic acids, serve as a mild and efficient method for the preparation of $\gamma$-amino acids and macrocyclic lactones. Org. Lett. 2009, 11, 4652-4655. [PubMed]

25. Nishikawa, K.; Yoshimi, Y.; Maeda, K.; Morita, T.; Takahashi, I.; Itou, T.; Inagaki, S.; Hatanaka, M. Radical photocyclization route for macrocyclic lactone ring expansion and conversion to macrocyclic lactams and ketones. J. Org. Chem. 2013, 78, 582-589. [CrossRef] 
26. Yamawaki, M.; Ukai, A.; Kamiya, Y.; Sugihara, S.; Sakai, M.; Yoshimi, Y. Metal-Free Photoinduced decarboxylative radical polymerization using carboxylic acids as benign radical initiators: Introduction of complex molecules into polymer chain ends. ACS Macro Lett. 2017, 6, 381-385. [CrossRef]

27. Kubosaki, S.; Takeuchi, H.; Iwata, Y.; Tanaka, Y.; Osaka, K.; Yamawaki, M.; Morita, T.; Yoshimi, Y. Visible and UV-light-induced decarboxylative radical reactions of benzoic acids using organic photoredox catalysts. J. Org. Chem. 2020, 85, 5362-5369. [CrossRef]

28. Iwata, Y.; Tanaka, Y.; Kubosaki, S.; Morita, T.; Yoshimi, Y. A strategy for generating aryl radicals from arylborates through organic photoredox catalysis: Photo-Meerwein type arylation of electron-deficient alkenes. Chem. Commun. 2018, 54, 1257-1260. [CrossRef] [PubMed]

29. Yoshimi, Y.; Itou, T.; Hatanaka, M. Redox-photosensitized reaction of indene using photosensitive surfactant in emulsion: Dependence on oil droplet size and surfactant charge. Tetrahedron Lett. 2006, 47, 3257-3260. [CrossRef]

30. Yamawaki, M.; Asano, A.; Furutani, T.; Izumi, Y.; Tanaka, Y.; Osaka, K.; Morita, T.; Yoshimi, Y. Photoinduced electron transferpromoted reactions using exciplex-type organic photoredox catalyst directly linking donor and acceptor arenes. Molecules 2019, 24, 4453. [CrossRef]

31. Tanaka, Y.; Kubosaki, S.; Osaka, K.; Yamawaki, M.; Morita, T.; Yoshimi, Y. Two types of cross-coupling reactions between electron-rich and electron-deficient alkenes assisted by nucleophilic addition using organic photoredox catalyst. J. Org. Chem. 2018, 83, 13625-13635. [CrossRef]

32. Maeda, K.; Saito, H.; Osaka, K.; Nishikawa, K.; Sugie, M.; Morita, T.; Takahashi, I.; Yoshimi, Y. Direct modification of tripeptides using photoinduced decarboxylative radical reactions. Tetrahedron 2015, 71, 1117-1123. [CrossRef]

33. Osaka, K.; Sugie, M.; Yamawaki, M.; Morita, T.; Yoshimi, Y. N-Acryloyl amino acid esters and peptides as radical acceptors in photoinduced decarboxylative radical reaction. J. Photochem. Photobiol. A 2016, 317, 50-55. [CrossRef]

34. Yamamoto, T.; Iwasaki, T.; Morita, T.; Yoshimi, Y. A strategy for $O$-alkylation of serine and threonine from serinyl and threoninyl acetic acids by photoinduced decarboxylative radical reactions: Connection between serine/threonine and carbohydrates/amino acids at the side chain. J. Org. Chem. 2018, 83, 3702-3709. [CrossRef]

35. Osaka, K.; Usami, A.; Iwasaki, T.; Yamawaki, M.; Morita, T.; Yoshimi, Y. Sequential intermolecular radical addition and reductive radical cyclization of tyrosine and phenylalanine derivatives with alkenes via photoinduced decarboxylation: Access to ring-constrained $\gamma$-amino acids. J. Org. Chem. 2019, 84, 9480-9488. [CrossRef] [PubMed]

36. Gieseler, A.; Steckhan, E.; Wiest, O.; Knoch, F. Photochemically induced radical-cation Diels-Alder reaction of indole and electron-rich dienes. J. Org. Chem. 1991, 56, 1405-1411. [CrossRef]

37. Wiest, O.; Steckhan, E. Radical cation Diels-Alder reaction of indoles and exocyclic dienes. Tetrahedron Lett. $1993,34,6391$. [CrossRef]

38. González-Béjar, M.; Stiriba, S.-E.; Miranda, M.A.; Pérez-Prietoa, J. Diels-Alder reaction between indoles and cyclohexadienes photocatalyzed by a (thia)pyrylium salt. ARKIVOC 2007, 4, 344-355. [CrossRef]

39. Muneer, M.; Saquib, M.; Qamar, M.; Bahnemann, D. Photocatalyzed reaction of indole in an aqueous suspension of titanium dioxide. Res. Chem. Intermed. 2010, 36, 121-125. [CrossRef]

40. Zhang, C.; Li, S.; Bureš, F.; Lee, R.; Ye, X.; Jiang, Z. Visible light photocatalytic aerobic oxygenation of indoles and pH as a chemoselective switch. ACS Catal. 2016, 6, 6853-6860. [CrossRef]

41. Wu, K.; Fang, C.; Kaur, S.; Liu, P.; Wang, T. Methylene blue-catalyzed oxidative cleavage of N-carbonylated indoles. Synthesis 2018, 50, 2897-2907.

42. Festa, A.A.; Voskressensky, L.G.; Van der Eycken, E.V. Visible lightmediated chemistry of indoles and related heterocycles. Chem. Soc. Rev. 2019, 48, 4401-4423. [CrossRef]

43. Zhang, Y.; Ji, P.; Gao, F.; Dong, Y.; Huang, H.; Wang, C.; Zhou, Z.; Wang, W. Organophotocatalytic dearomatization of indoles, pyrroles and benzo(thio)furans via a Giese-type transformation. Commun. Chem. 2021, 4, 20. [CrossRef]

44. Zhang, M.; Duan, Y.; Li, W.; Cheng, Y.; Zhu, C. Visible-light-induced aerobic dearomative reaction of indole derivatives: Access to heterocycle fused or spirocyclo indolones. Chem. Commun. 2016, 52, 4761-4763. [CrossRef]

45. Wang, Q.; Qu, Y.; Xia, Q.; Song, H.; Song, H.; Liu, Y.; Wang, Q. Visible-light-mediated dearomatization/cyanation cascade reaction of indoles: Access to highly functionalized spiro- $\gamma$-lactam indolines with two contiguous sterically congested quaternary carbon stereocenters. Adv. Synth. Catal. 2018, 360, 2879-2884. [CrossRef]

46. Guirado, G.; Fleming, C.N.; Lingenfelter, T.G.; Williams, M.L.; Zuihof, H.; Dinnocenzo, J.P. Nanosecond redox equilibrium method for determining oxidation potentials in organic media. J. Am. Chem. Soc. 2004, 126, 14086-14094. [CrossRef] [PubMed]

47. Yoshimi, Y.; Hayashi, S.; Nishikawa, K.; Haga, Y.; Maeda, K.; Morita, T.; Itou, T.; Okada, Y.; Ichinose, N.; Hatanaka, M. Influence of solvent, electron acceptors, and arenes on photochemical decarboxylation of free carboxylic acid via single electron transfer (SET). Molecules 2010, 15, 2623-2630. [CrossRef]

48. Lee, S.; Yi, K.Y.; Yoo, S. Introduction of heterocycles at the 2-position of indoline as ester bioisosteres. Bull. Korean Chem. Soc. 2004, 25, 207-212. [CrossRef]

49. Yamawaki, M.; Okita, Y.; Yamamoto, T.; Morita, T.; Yoshimi, Y. Photoinduced electron transfer-promoted debenzylation of phenylalanine and tyrosine derivatives using dicyanoarene. Tetrahedron 2017, 73, 7239-7244. [CrossRef]

50. Roth, H.G.; Romero, N.A.; Nicewicz, D.A. Experimental and calculated electrochemical potentials of common organic molecules for applications to single-electron redox chemistry. Synlett 2016, 27, 714-723. 